\title{
VALUATING PATENTS GENERATED BY PUBLIC RESEARCH CENTERS WITH THE AHP TECHNIQUE.
}

\author{
Mónica García Melón* \\ INGENIO (Instituto mixto CSIC-UPV) \\ Universitat Politècnica de València \\ mgarciam@dpi.upv.es \\ Rafael López \\ PONS Patentes y Marcas \\ rlopez@pons.es \\ Pablo Aragonés Beltrán \\ INGENIO (Instituto mixto CSIC-UPV) \\ Universitat Politècnica de València \\ aragones@dpi.upv.es \\ Enrique San Ambrosio \\ ensaam@etsii.upv.es
}

\begin{abstract}
The technology transfer offices (TTO) of public research centers seek to support researchers who have developed patents of commercial value which may attract companies interested in exploiting them.

The problem faced by each institution's TTO is how to determine the value of those patents that could eventually lead to signing a satisfactory agreement between the institution and the company interested in the patent

The valuation of patents is a complex problem because it depends on the context the patent is developed and on multiple criteria associated with the knowledge area to which it belongs.

The main assumption of the present paper is whether the AHP method can be applied to help solve this problem, based on a previous experience in which the research group successfully applied the same approach to value tangible assets (properties, agricultural and industrial parcels, parks, ...).

The methodological approach presented in this paper will allow TTOs to optimize the techniques used to value patents and make this process more systematic, traceable and transparent.
\end{abstract}

Keywords: patent valuation, AHP

\section{Introduction}

In the knowledge era in which technology is developing rapidly the value of intangible assets has gained tremendous importance in recent years. Patents play a leading role among intangible assets as they contribute to value companies, give them more prestige and improve their R\&D activities. However, patents are difficult to assess because they not only are one type of

\footnotetext{
${ }^{*}$ Corresponding author
} 
intangible asset, but are also a right (Lai and Che, 2009). According to Chen and Chang (2010), the competitive advantages of companies are now less frequently based on allocation of physical assets and increasingly based on intangible assets, such as patents. The task of assigning value to patent rights is particularly difficult (Harhoff et al., 2003).

In the past 20 years, academic researchers such as Narin et al. (1987), Trajtenberg (1990) and Hall et al. (2001), have developed several models that essentially aim at finding a proper weighting scheme for valuing patents, or the identification of the most promising patents in the vast ocean of encoded knowledge published each year by the major patent offices. Several empirical approaches have been used to estimate the value of a patent. They are based on data sets that cover different time periods and use different data sources. The functional architecture of these empirical models greatly varies. Some authors use the monetary value of the patents (Harhoff et al., 1999, 2003), their current value assigned by experts based on a scoring scale (Reitzig, 2003), patent citations (Lerner, 1994), a combined indicator (Lanjouw and Schankerman, 1999), the probability of obtaining a licensed patent (Guellec and van Pottelsberghe, 2000), patent opposition and data update (Pakes and Simpson, 1989, Lanjouw and Schankerman, 1999), if the patent develops a new high-technology or it is built on codified inventions (Shane, 2001). There are some more holistic approaches: (Sapsalis et al. 2006), focus in comparing criteria that define the value of academic and corporate patens and (Chiu and Cheng, 2007) use the AHP to asses a ranking of patents value to patents according to different criteria of different types. However, these authors did not assign a monetary value to the patents they analyzed.

This paper presents a model of patent valuation based on the AHP technique, the aim being to assess a monetary value by compering the problem patent with other patents whose market value is known.

AHP has been successfully used by the authors to evaluate real estate and intangible assets (Aragonés-Beltrán et al., 2008), (Garcia-Melon et al., 2008). The valuation model uses explanatory variables (evaluation criteria) and comparable assets (similar patents) to estimate the value of unknown new patents based on the AHP technique.

In the following the methodology used and the results of its application are presented.

\section{Methodology followed:}

The approach used to build the patent valuation model is as follows:

\begin{tabular}{|l|l|}
\hline 1 & - Definition of the problem \\
\hline 2 & -Analysis of the criteria. \\
\hline 3 & -Weighting of criteria \\
\hline 4 & -Search for comparable patents \\
\hline 5 & -Valuation of the patent with AHP \\
\hline
\end{tabular}

Figure 1. Methodology proposed

\subsection{Definition of the problem}

The aim of this work is to develop a patent valuation model based on the AHP technique. The model should be applicable to patents belonging to any technological field. The model uses explanatory variables (evaluation criteria) some of which were obtained from bibliographic sources and others upon the recommendation of the experts. The evaluation criteria must be 
generic enough to be applicable to any kind of patent. For the valuation of each patent two similar patents with known and updated economic value are used as comparable assets.

For the development of the model the authors had the collaboration of expert patent evaluators from the UPV TTO (Technology Transfer Office of the Universidad Politecnica de Valencia) and from a Spanish patents and trademarks company.

\subsection{Analysis of the criteria}

\subsubsection{Criteria proposed in the literature.}

We are in a field of study that, although of a great importance in the world economy, is poorly researched. There are many possible approaches to address the problem. Additionally, there is a wide disparity in the terminology used for the valuation of patents in the literature. Below is a list of the criteria found in the literature and their source.:

Table 1. List of criteria obtained from the literature

\begin{tabular}{|c|c|c|}
\hline criterion & description & source \\
\hline $\begin{array}{l}\text { Patent } \\
\text { protection }\end{array}$ & $\begin{array}{l}\text { This indicator refers to the scope of protection of the patent, } \\
\text { i.e., the number of countries where it has been protected }\end{array}$ & $\begin{array}{l}\text { Sapsalis et } \\
\text { al.(2006) }\end{array}$ \\
\hline $\begin{array}{l}\text { Backward } \\
\text { patent citations } \\
\text { (BPC) }\end{array}$ & $\begin{array}{l}\text { This indicator measures the technological knowledge of the } \\
\text { patent, i.e., the number of backward patent citations. The } \\
\text { greater the number of BPCs, the more valuable the patent is, } \\
\text { and more so if the citations refer to patents from industry } \\
\text { (higher market value). }\end{array}$ & $\begin{array}{l}\text { Sapsalis et } \\
\text { al.(2006) }\end{array}$ \\
\hline $\begin{array}{l}\text { Non patent } \\
\text { citations }\end{array}$ & $\begin{array}{l}\text { This indicator measures the scientific knowledge of the } \\
\text { patent. It consists of the number of citations to scientific } \\
\text { literature (e.g. research papers) containing the patent }\end{array}$ & $\begin{array}{l}\text { Sapsalis et } \\
\text { al.(2006) }\end{array}$ \\
\hline $\begin{array}{l}\text { Non self non } \\
\text { patent citations }\end{array}$ & $\begin{array}{l}\text { This indicator measures the number of citations of articles } \\
\text { written by others (not by the inventor) that contain the } \\
\text { patent. }\end{array}$ & $\begin{array}{l}\text { Sapsalis et } \\
\text { al.(2006) }\end{array}$ \\
\hline $\begin{array}{l}\text { Self non-patent } \\
\text { citations }\end{array}$ & $\begin{array}{l}\text { This indicator measures the number of citations of articles } \\
\text { written by the researcher about his/her patent. Studies } \\
\text { indicate that these citations add more value to the patent, as } \\
\text { they show the experience of the researcher in the patent's } \\
\text { field, and the likely commercial success of the patent. }\end{array}$ & $\begin{array}{l}\text { Sapsalis et } \\
\text { al.(2006) }\end{array}$ \\
\hline $\begin{array}{l}\text { Cooperation } \\
\text { (Co-assignees) }\end{array}$ & $\begin{array}{l}\text { A patent can have more than one inventor, they are called } \\
\text { co-assignees. This criterion measures the number of co- } \\
\text { assignees of a patent. To determine more accurately the } \\
\text { value they bring to the patent, it is necessary to distinguish } \\
\text { whether the co-assignees are from an industrial sector or a } \\
\text { public institution }\end{array}$ & $\begin{array}{l}\text { Sapsalis et } \\
\text { al.(2006) }\end{array}$ \\
\hline $\begin{array}{l}\text { Corporate co- } \\
\text { assignees }\end{array}$ & $\begin{array}{l}\text { This criterion indicates that the co-assignee is from an } \\
\text { industrial sector }\end{array}$ & $\begin{array}{l}\text { Sapsalis et } \\
\text { al.(2006) }\end{array}$ \\
\hline $\begin{array}{l}\text { Public co- } \\
\text { assignees }\end{array}$ & $\begin{array}{l}\text { This criterion indicates that the co-assignee is from a public } \\
\text { institution. The patent is expected to have greater value if the } \\
\text { co-assignees are from public institutions than if they come } \\
\text { the industrial sector }\end{array}$ & $\begin{array}{l}\text { Sapsalis et } \\
\text { al.(2006) }\end{array}$ \\
\hline $\begin{array}{l}\text { Number of } \\
\text { years a patent is } \\
\text { renewed }\end{array}$ & $\begin{array}{l}\text { It refers to the number of years that a patent has been } \\
\text { renewed; it is an indicator of the value of a patent. }\end{array}$ & $\begin{array}{l}\text { Sapsalis et } \\
\text { al.(2006) }\end{array}$ \\
\hline
\end{tabular}




\begin{tabular}{|c|c|c|}
\hline $\begin{array}{l}\text { Monetary } \\
\text { patent value } \\
\text { Forward patent } \\
\text { citation }\end{array}$ & $\begin{array}{l}\text { It indicates the economic value of a patent. It is a direct } \\
\text { indicator of the value of a patent value, but it is difficult to } \\
\text { know this value. } \\
\text { It refers to the number of citations of a patent in subsequent } \\
\text { patents. Studies indicate that this indicator is closely related } \\
\text { to the value of a patent. The greater the number of FPC, the } \\
\text { greater the value of the patent }\end{array}$ & $\begin{array}{l}\text { Sapsalis et } \\
\text { al.(2006) } \\
\text { Sapsalis et } \\
\text { al.(2006) }\end{array}$ \\
\hline Age patent & $\begin{array}{l}\text { The older the priority date (year of first presentation) of a } \\
\text { patent is, the more likely it is to be cited in subsequent } \\
\text { patents; the number of FPC will then be greater and } \\
\text { consequently the patent will have greater value }\end{array}$ & $\begin{array}{l}\text { Sapsalis et } \\
\text { al.(2006) }\end{array}$ \\
\hline Inventors & $\begin{array}{l}\text { This indicator measures the number of inventors listed in the } \\
\text { patent. It is necessary to distinguish the origin of the } \\
\text { inventors, because in industry, the larger the number of } \\
\text { inventors the greater the value of the patent, whereas in the } \\
\text { academic sector it is the opposite, i.e., the fewer the } \\
\text { members in the research group the greater the value of the } \\
\text { patent. }\end{array}$ & $\begin{array}{l}\text { Sapsalis et } \\
\text { al.(2006) }\end{array}$ \\
\hline $\begin{array}{l}\text { Relative patent } \\
\text { position }\end{array}$ & $\begin{array}{l}\text { This criterion measures the number of patents a company has } \\
\text { in its most important technological field (the area in which it } \\
\text { has the largest number of patents), divided by the number of } \\
\text { patents of the leader company in this field. With this } \\
\text { criterion it is possible to determine the degree of } \\
\text { specialization of a company in a particular technological } \\
\text { field. The higher the RPP is, the higher market value the } \\
\text { company will have.. }\end{array}$ & $\begin{array}{l}\text { Cheng and } \\
\text { Chan (2010) }\end{array}$ \\
\hline \begin{tabular}{l|} 
Herfindahl- \\
Hirschman \\
Index of patents
\end{tabular} & $\begin{array}{l}\text { This criterion measures the degree of concentration of a } \\
\text { technology company (between } 0 \text { and } 1 \text { ). If HHI equals } 1 \text {, it } \\
\text { means that all the company's patents belong to the same } \\
\text { technological field, i.e., the company's technology is highly } \\
\text { concentrated. The higher the HHI is, the lower the market } \\
\text { value of the company. }\end{array}$ & $\begin{array}{l}\text { Cheng and } \\
\text { Chan (2010) }\end{array}$ \\
\hline $\begin{array}{l}\text { Reveal } \\
\text { technology } \\
\text { advantage }\end{array}$ & $\begin{array}{l}\text { This criterion measures the budget allocated by a company } \\
\text { to the patents belonging to a particular technological field } \\
\text { divided by the budget allocated to all patents. The higher the } \\
\text { RTA, the greater the relative strength of a company in a } \\
\text { given technological field. However, studies show that the } \\
\text { higher the RTA, the lower the market value of the company. }\end{array}$ & $\begin{array}{l}\text { Cheng and } \\
\text { Chan (2010) }\end{array}$ \\
\hline Science linkage & $\begin{array}{l}\text { Average number of citations to other references that appear } \\
\text { on the cover of a patent, including journal articles and papers } \\
\text { presented at scientific meetings.. }\end{array}$ & $\begin{array}{l}\text { Chiu and } \\
\text { Chen (2007) }\end{array}$ \\
\hline $\begin{array}{l}\text { Technology } \\
\text { cycle time }\end{array}$ & $\begin{array}{l}\text { Average time (in years) of the youngest U.S. patents } \\
\text { referenced on the cover of a U.S. patent. }\end{array}$ & $\begin{array}{l}\text { Chiu and } \\
\text { Chen (2007) }\end{array}$ \\
\hline $\begin{array}{l}\text { Current impact } \\
\text { index }\end{array}$ & $\begin{array}{l}\text { Number of citations generated by a company's patents in the } \\
\text { last five years, divided by the expected number of citations } \\
\text { of other comparable high-tech companies }\end{array}$ & $\begin{array}{l}\text { Chiu and } \\
\text { Chen (2007) }\end{array}$ \\
\hline
\end{tabular}




\begin{tabular}{|l|l|l|} 
Number of IPC & $\begin{array}{l}\text { It is a 4-digit number that is used to classify patents. This is a } \\
\text { hierarchical system that divides technology into 60,000 } \\
\text { categories; this number allows an estimation of the scope of } \\
\text { the patent. }\end{array}$ & $\begin{array}{l}\text { Harhoff et } \\
\text { al.(2003) }\end{array}$ \\
\hline
\end{tabular}

\subsubsection{Criteria proposed by experts}

The assistance of two experts of a patent management company was required. They reviewed the list of criteria obtained from the literature, eliminated some of them and proposed new ones according to their expertise.

Table 2. List of criteria proposed by the experts according to their expertise

\begin{tabular}{|l|l|}
\hline Patentability requirements & $\begin{array}{l}\text { Patents are granted for new inventions which involve an inventive } \\
\text { activity and are susceptible of industrial application }\end{array}$ \\
\hline Fall-back options & $\begin{array}{l}\text { One part of the application form for a patent is the descriptive report. } \\
\text { The descriptive report supports the patent claims and provides a } \\
\text { sufficient explanation of the invention so that a qualified expert in the } \\
\text { field can reproduce it. The fall-back options are dependent claims that } \\
\text { have a lower level of protection than the independent ones. The patent } \\
\text { may be granted if the applicant renounces the independent claim and } \\
\text { selects a preferred embodiment of the invention. }\end{array}$ \\
\hline Divisional applications & $\begin{array}{l}\text { If the patent office decides that the scope of the patent is too broad to be } \\
\text { considered a single patent, it may be divided into a number of } \\
\text { divisional applications that the applicant is free to present or not. The } \\
\text { applicant can also file a divisional application at anytime }\end{array}$ \\
\hline Relative patent position & $\begin{array}{l}\text { Patent position in the group of patents covering similar material (i.e., } \\
\text { which addresses the same technical problem). }\end{array}$ \\
\hline Scope of the subject matter of a patent & $\begin{array}{l}\text { The claims consist of a written report of the abstract inventive concept } \\
\text { created by the inventor. They indicate exactly what the applicant } \\
\text { considers his invention is. They set the outer limits of the protection of } \\
\text { industrial property rights. There are of different types, products and } \\
\text { processes (including applications and methods). }\end{array}$ \\
\hline Triadic & $\begin{array}{l}\text { This criterion refers to whether the patent has been filed simultaneously } \\
\text { in the USPTO, JPO and EPO }\end{array}$ \\
\hline Freedom of operation & $\begin{array}{l}\text { The owner of the patent or any allowed person may freely exploit the } \\
\text { patent provided there is no other patent in the State in which the patent } \\
\text { is to be exploited that covers the claimed subject matter. In the event of } \\
\text { the existence of other patents then it would be necessary to get } \\
\text { permission for exploitation. Pending patent applications must also be } \\
\text { taken into consideration }\end{array}$ \\
\hline
\end{tabular}

\subsubsection{Final model of criteria. Construction of AHP model.}

At the end, a final list of criteria was proposed and a hierarchical model that included all the criteria considered important for the valuation of patents was built. These two same experts were necessary for the weighting of the criteria.

The criteria were arranged into groups in order to build a hierarchical structure.

Table 3. List of criteria

C1: Inherent features of the patent

\begin{tabular}{|l|l|}
\hline C1.1 & Patentability requirements \\
\hline C1.2 & Fall-back options \\
\hline
\end{tabular}




\begin{tabular}{|l|l|l|}
\hline \multirow{2}{*}{} & C1.3 & Divisional applications \\
\cline { 2 - 3 } & C1.4 & Relative patent position \\
\cline { 2 - 3 } & C1.5 & Scope of the subject matter \\
\hline \multirow{3}{*}{ C2: Patent strengths } & C2.1 & Family size \\
\cline { 2 - 3 } & C2.2 & Triadic \\
\cline { 2 - 3 } & C2.3 & Litigations \\
\hline \multirow{3}{*}{ C3: Staff } & C3.1 & Inventors \\
\cline { 2 - 3 } & C3.2 & Self non-patent citations \\
\cline { 2 - 3 } & C3.3 & Cooperation (Co-assignees) \\
\hline \multirow{2}{*}{ C4: Freedom } & C4 & $\begin{array}{l}\text { Free exploitation of the claimed subject } \\
\text { matter }\end{array}$ \\
\hline
\end{tabular}

The hierarchical structure built was the following:

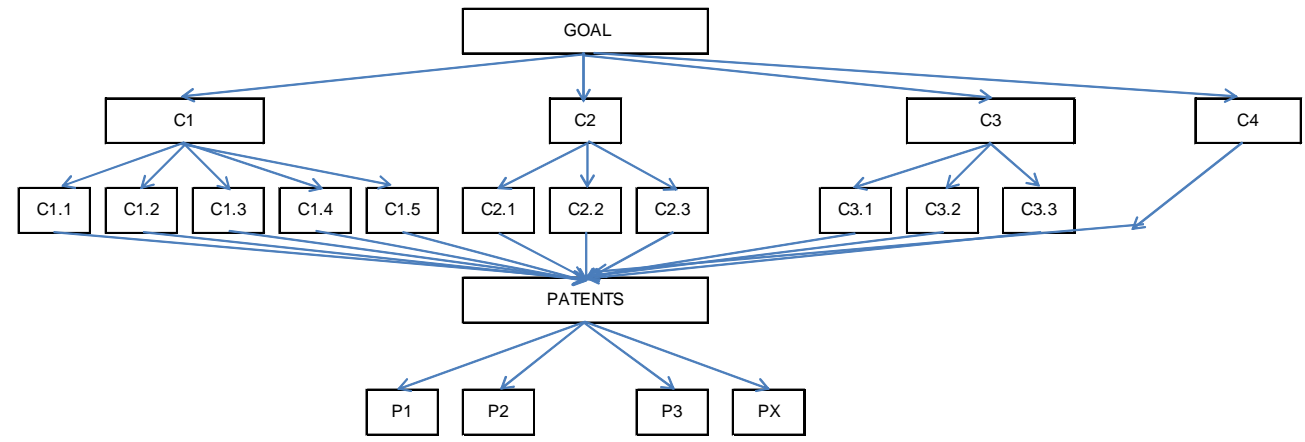

Figure 2. Hierarchical structure of the valuation model

\subsection{Weighting of the criteria}

Questionnaires based on pairwise questions for the priotitization of the criteria were developed and answered by the experts.

The resulting weights of the criteria are presented in the following table:

Table 4. Criteria weights

C1: Inherent features of the patent $(0,574)$

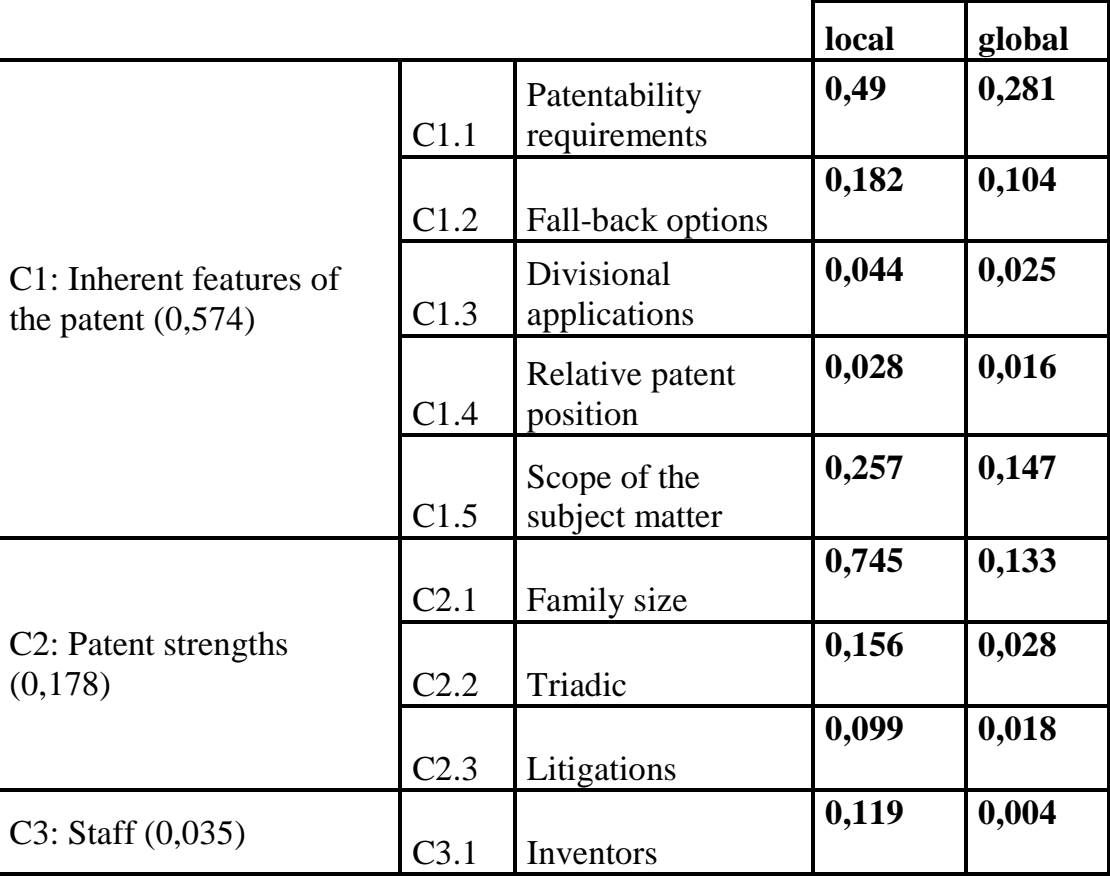




\begin{tabular}{|l|l|l|l|l|} 
& C3.2 & $\begin{array}{l}\text { Self non-patent } \\
\text { citations }\end{array}$ & $\mathbf{0 , 7 4 7}$ & $\mathbf{0 , 0 2 6}$ \\
\cline { 2 - 5 } & C3.3 & $\begin{array}{l}\text { Cooperation (Co- } \\
\text { assignees) }\end{array}$ & $\mathbf{0 , 1 3 4}$ & $\mathbf{0 , 0 0 5}$ \\
\hline C4: Freedom $(0,213)$ & C4 & $\begin{array}{l}\text { Free exploitation of } \\
\text { the claimed subject } \\
\text { matter }\end{array}$ & $\mathbf{1}$ & $\mathbf{0 , 2 1 3}$ \\
\hline
\end{tabular}

All the weights are calculated in the distributive mode.

\subsection{Search for comparable patents}

For this step, finding similar patents for use as comparables, we used commercial databases to access that information. We looked for patents in the same field of knowledge, whose selling price was known. That was probably the hardest part because data bases are of difficult access and also they provide scarce information. For the correct application of the methodology at least three comparable patents are required.

Our study analyzes a patent on a product that belongs to the field of Sleep disorders. Three comparable patents in the same field of knowledge and with recent economic transactions were used as comparables. The names of the patents and agreements are not shown due to confidentiality reasons.

Table 5. Data about the different patents analyzed

\begin{tabular}{|c|c|c|c|c|c|c|}
\hline $\begin{array}{l}\text { Name } \\
\text { of the } \\
\text { patent }\end{array}$ & $\begin{array}{c}\mathrm{N} \text { of patent } \\
\text { license } \\
\text { agreemement }\end{array}$ & Upfront fee & Royalty & $\begin{array}{l}\text { Additiona } \\
\text { payments }\end{array}$ & $\begin{array}{c}\text { Total amount } \\
\text { without } \\
\text { approval }\end{array}$ & $\begin{array}{c}\text { Total amount } \\
\text { with all the } \\
\text { approvals } \\
\end{array}$ \\
\hline$\overline{\mathrm{P} 1}$ & 831 & 300.000 & 9 & $\begin{array}{l}\text { - } 250.000 \text { for NDA } \\
\text { approval } \\
\text { - mínimum of } 250 \\
\text { for royalties }\end{array}$ & 550.000 & 800.000 \\
\hline P2 & 18.511 & 2.500 .000 & 7 & $\begin{array}{l}-5.000 .000 \text { for } \\
\text { NDA acceptation } \\
-10.000 .000 \text { for } \\
\text { NDA approval } \\
\\
-150.000 \text { for the } \\
\text { hospital when } \\
\text { entering clinical } \\
\text { tests phase II }\end{array}$ & 2.650 .000 & 17.650 .000 \\
\hline $\bar{P} 3$ & 20.854 & 50.000 & 19 & $\begin{array}{l}-3.000 .000 \\
\text { depending on the } \\
\text { product } \\
-10.000 .000 \text { for use } \\
\text { is sleep } \\
\text { manteinance } \\
-10.000 .000 \text { for } \\
\text { NDA approval } \\
-5.000 .000 \text { for use } \\
\text { label removal }\end{array}$ & 13.050 .000 & 51.050 .000 \\
\hline
\end{tabular}




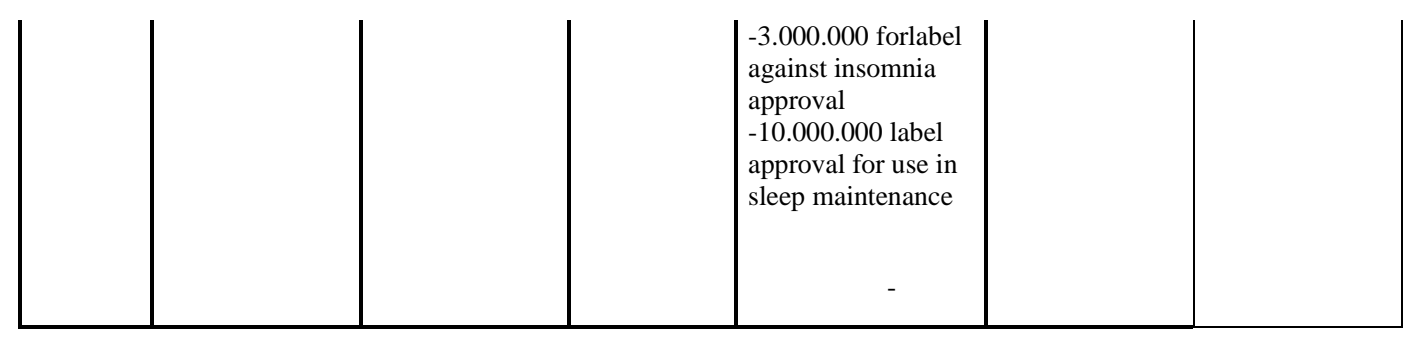

\subsection{Valuation of the problem patent with AHP/AMUVAM.}

AHP will be used to prioritise and weight the reference patents and the problem patent.

According to (Aznar and Guijarro 2004) it is necessary to obtain a ratio that compares the weight of the problem patent with its market value. This ratio can be calculated as the quotient of the sum of all the market values of the reference patents, known by the valuator, and the sum of all their weights, obtained with the AHP.

The problem patent value can be calculated by multiplying the value/weighting ratio by the problem patent weight obtained with AHP. The valuator will have to analyse if this value is reasonable and makes sense in order to decide whether to accept it or to reject it.

The expert answered the questionnaires about the alternatives and values them according to the previously defined criteria.

The results are shown in the following table:

Table 6. Results of the values of the different patents

\begin{tabular}{|l|l|l|l|l|}
\hline & AHP value & $\begin{array}{l}\text { selling price of } \\
\text { the patent } \\
\text { (US\$) }\end{array}$ & $\begin{array}{l}\text { updated selling price } \\
\text { (5\% annual)(US\$) }\end{array}$ & ratio \\
\hline p1 & 0,345 & 800000 & 1583945 & 4591145,74 \\
\hline p2 & 0,213 & 17650000 & 17650000 & 82863849,8 \\
\hline p3 & 0,277 & 51050000 & 75424100 & 272289171 \\
\hline pX & 0,165 & & $\mathbf{1 8 7 0 4 8 8 3}$ & \\
\hline
\end{tabular}

So, in this case, and according to the valuation method proposed in this paper, the Patent $\mathrm{X}$ should be sold for 18.704.883 US\$.

\section{Discussion and conclusions}

In this paper the AHP has been applied to patent valuation. It has proven to be especially useful when data are only partially available, qualitative variables are used and influences among the explanatory variables are present. It can be adapted to any kind of patents, provided the explanatory variables and reference patents be correctly identified.

However, we want to emphasize that we have found that market values are not correlated with AHP values. That means that building a model only with technical criteria does not show the whole picture of the value of the patent. We conclude that it would be essential to take into account also the market-related aspects, which have not been analysed in this model. For that, this model does not substitute yet any of the previous mentioned models (Harhoff et al., 2003), (Sapsalis et al. 2006) but rather complements them. 
We would recommend its use for rank ordering patents rather than for valuing them. The model provides a technological index for each patent which in term can be used to prioritize the patent portfolio of a company.

We can conclude, therefore, that the technical assessment of a patent is not enough to reach the market value. Our next step will be to combine the technical, market, legal and investment aspects in order to asses a more realistic value. 


\section{REFERENCES}

Aragonés-Beltrán P., Aznar J., Ferrís-Oñate J., García-Melón M., 2008, Valuation of Urban Industrial Land: an Analytic Network Process Approach, European Journal of Operational Research 185, 322-339

Aznar J., Guijarro F., 2007, Estimating regression parameters with imprecise input data in an appraisal context, European Journal of Operational Research 176(3), 1896-1907

Chen Y-S, Chang K-C, 2010, The relationship between a firm's patent quality and its market value. The case of US pharmaceutical industry, Technological Forecasting \& Social Change 77 20-33

Chiu Y-J, Yuh-Wen Chen Y-W, 2007, Using AHP in patent valuation, Mathematical and Computer Modelling 46, 1054-1062

García-Melón M.; Ferrís-Oñate J.; Aznar J.; Aragonés-Beltrán P.; Poveda-Bautista R., 2008, Farmland appraisal based on the Analytic Network Process, Journal of Global Optimization 42 143-155.

Guellec D., van Pottelsberghe B., 2000, Applications, grants and the value of patent, Economics Letters, 69, 1, 109-114

Hall B.H., MacGarvieb M., 2001, The private value of software patents, Research Policy 39, 994-1009

Harhoff D., Scherer F.M., Vopel K., 2003, Citations, family size, opposition and the value of patent rights, Research Policy 32, 1343-1363

Lanjouw JO, Schankerman M., 2001, Characteristics of patent litigation: a window on competiton, RAND Journal of economics, 32, 1, 129-151

Lerner J., 1994, The importance of patent scope: an empirical analysis, The RAND journal of economics, 25,2

Narin F., Noma E, Perry R., 1987, Patents as indicators of corporate technological strength, Research Policy, 16, 143-155

Pakes A., Simpson M., 1989, Patent renewal data, Brooking Institution Press

Reitzig M., 2003, What determines patent value? Insights from the semiconductor industry, Research Policy 32, 13-26

Sapsalis E., Van Pottelsbergue B., 2007, The institutional sources of knowledge and the value of academic patents, Econ. Innov. New Techn., Vol. 16(2), 139-157

Sapsalis E., Van Pottelsbergue B , Navon R., 2006, Academic versus industry patenting: An indepth analysis of what determines patent value, Research Policy 35 1631-1645

Shane S., 2001, Technology regimes and new firm formation, Management Science, 47, 11731190

Trajtenberg M., 1990, A Penny for your quotes: patent citations and the value of innovations, The rand journal of economics, 1, 21

Yi-Hsuan Lai Y-H, Che H-C, 2009, Evaluating patents using damage awards of infringement lawsuits: A case study, J. Eng. Technol. Manage. 26, 167-180 